\title{
Biomass and elemental composition (C, N, H) of the periphytic community attached to Polygonum punctatum Ell. in a subtropical reservoir and its relationship to environmental factors
}

\author{
Ricardo Hideo Taniwaki ${ }^{1, *}$, Albano Geraldo Emílio Magrin ${ }^{2}$, Maria do Carmo Calijuri ${ }^{3}$ and \\ Viviane Moschini Carlos ${ }^{1}$ \\ ${ }^{1}$ UNESP-Universidade Estadual Paulista "Júlio de Mesquita Filho", Av. Três de Março 511, CEP 18087-180, \\ Sorocaba, SP, Brazil. \\ ${ }^{2}$ UFSCar-Universidade Federal de São Carlos, Rod. João Leme dos Santos 110-SP 264, CEP 18052-780, \\ Sorocaba, SP, Brazil. \\ ${ }^{3}$ EESC-USP-Escola de Engenharia de São Carlos, Universidade de São Paulo, Av. Trabalhador Sãocarlense 400, \\ CEP 13566-590, São Carlos, SP, Brazil.
}

* Corresponding author: rht.eco@usp.br

Received: 21/09/2012 Accepted: 20/06/2013

\begin{abstract}
Biomass and elemental composition $(\mathrm{C}, \mathrm{N}, \mathrm{H})$ of the periphytic community attached to Polygonum punctatum Ell. in a subtropical reservoir and its relationship to environmental factors

The periphytic communities in Brazilian reservoirs have been studied widely due to their importance for the assimilation of nutrients and their role at the base of the food chain. The objective of the present work was to analyse the environmental variables that influence the development of periphytic communities attached to stalks of the aquatic macrophyte Polygonum punctatum Ell. Five sample collections were made during 2010 at two sites in the Itupararanga reservoir (Ibiúna, São Paulo, Brazil). The macrophyte was collected, and the periphytic community attached to its stalks was scraped off with a brush and jets of distilled water. Using a PLS analysis, we observed that $94.3 \%$ of the variation in periphyton biomass could be explained by concentrations of nitrate, conductivity, dissolved oxygen, water clarity and dissolved inorganic phosphorous. According to the indices applied, in 2010 the biomass of the periphytic community in the reservoir was low and predominantly heterotrophic, and the concentration of carbon in the periphyton was lower than that found in previous studies of this community.
\end{abstract}

Key words: Carbon, elemental composition, periphyton, reservoir.

\section{RESUMEN}

Biomasa y composición elemental $(C, N, H)$ de la comunidad perifítica adjunta a Polygonum punctatum Ell. en un embalse subtropical y su relación con los factores ambientales

Las comunidades perifíticas en los embalses brasileños han sido ampliamente estudiadas debido a su importancia en la asimilación de nutrientes y su papel en la base de la cadena alimentaria. El objetivo del presente trabajo fue analizar las variables ambientales que influyen en el desarrollo de la comunidad perifítica adjunta a tallos de las macrófitas acuáticas Polygonum punctatum Ell. Cinco colecciones de muestras se realizaron en 2010 en dos sitios en el embalse Itupararanga (Ibiúna, São Paulo, Brasil). Las macrófitas se recogió, y la comunidad perifíticas adjunta a sus tallos se raspó con la ayuda de un cepillo y chorros de agua destilada A través del análisis de PLS, se observó que $94.3 \%$ de la variación en la biomasa de perifiton puede explicarse por la concentración de nitrato, conductividad, oxígeno disuelto, transparencia del agua y el fósforo inorgánico disuelto. De acuerdo con los índices utilizados, en 2010 la biomasa de la comunidad perifítica en el embalse es bajo y predominantemente heterótrofos, y la concentración de carbono en el perifiton fue menor que la encontrada en estudios previos de esta comunidad.

Palabras clave: Carbono, composición elemental, perifiton, embalse. 


\section{INTRODUCTION}

Environmental conditions govern both the development and biomass of periphytic communities in aquatic ecosystems (Moschini-Carlos et al., 2000; Elsdon \& Limburg, 2008; Guariento et al., 2009; Sanches et al., 2011). In reservoirs, knowledge concerning primary producers is especially important because these organisms can regulate the trophic chain via bottom-up effects, and the water in reservoirs is used for essential purposes such as human consumption, irrigation, recreation, and tourism (Tundisi \& Matsumura-Tundisi, 2003).

Changes in periphytic communities have been associated with a variety of anthropogenic impacts including land use and occupation (Elsdon \& Limburg, 2008), nutrient enrichment (Sanches et al., 2011), and the availability of light (Guasch \& Sabater, 1998; Sanches et al., 2011). All of these factors can act in conjunction to increase or decrease periphytic biomass in continental aquatic ecosystems.

Periphyton has been widely studied in Brazilian reservoirs with regards to its biomass (Moschini-Carlos et al., 2001; Ferragut et al., 2010), specific composition (Fermino et al., 2011), and primary productivity (Moschini-Carlos et al., 2000; Moschini-Carlos et al., 2001). However, very little information is available concerning its elemental composition, which could serve as a basis for comparisons between different environments or levels of environmental contamination. In addition to its well-known importance as a primary producer (Wetzel, 1963), the periphytic community is also extremely important to the carbon cycle in aquatic ecosystems, and in some cases is responsible for as much as $90 \%$ of organic matter production (Wetzel, 1990). According to Tranvik et al. (2009), alterations in aquatic ecosystems due to anthropogenic activity, as is the case for reservoirs, can cause hydrological and temperature changes that intensify the carbon cycle.

The present study was undertaken to identify the environmental variables that affect the biomass of periphytic community attached to the aquatic macrophyte Polygonum punctatum Ell. and to determine the contribution of this biomass

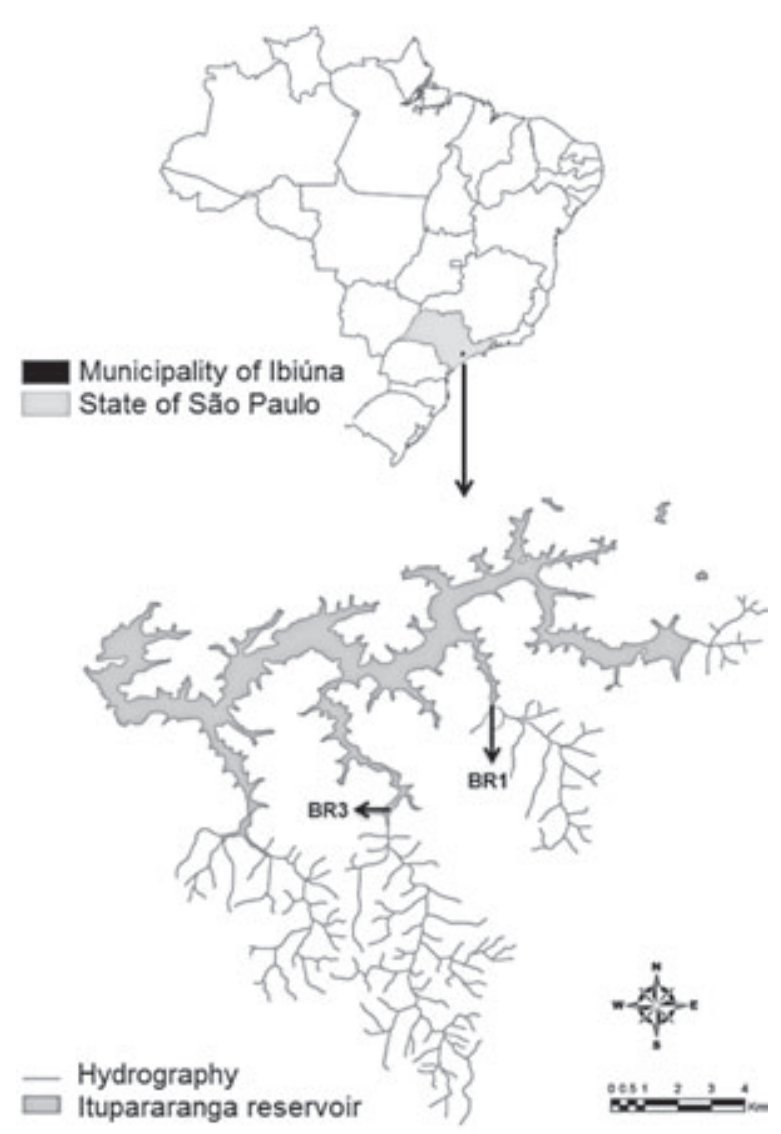

Figure 1. Location of Ibiúna municipality in São Paulo State and of the sampling stations in the Itupararanga reservoir. Localización de la ciudad de Ibiúna en el Estado de São Paulo y de las estaciones de muestreo en el embalse Itupararanga.

to the total carbon stock of a subtropical reservoir. Our hypothesis is that seasonality, through changes in hydrology, will exert some influence on both the biomass and elemental composition of this community in the Itupararanga reservoir.

\section{MATERIALS AND METHODS}

The Itupararanga reservoir (Ibiúna, São Paulo, Brazil) is located in the upper reaches of the Sorocaba River in southeastern Brazil, which is in the subtropical zone of the country. It receives water from the rivers Sorocabuçu and Sorocamirim, which together form the Sorocaba River (Smith \& Petrere Jr., 2008). The reservoir was constructed in 1914 for generating electricity 
(Cunha \& Calijuri, 2011) and occupies parts of the municipalities of Ibiúna, Piedade, São Roque, Mairinque, Alumínio, and Votorantim.

The principal types of land use in the hydrographic basin in which the reservoir is located (the Upper Sorocaba and Middle Tietê basin) are intensive agriculture (42.3\% of coverage) and smallholdings ( $4.2 \%$ of coverage), with the largest portion of the area dedicated to crop production (Sardinha et al., 2010; Conceição et al., 2011, Pedrazzi et al., 2013).

The Itupararanga reservoir supplies drinking water to a population of approximately 800000 , has a storage capacity of 286 million cubic meters of water, and a water residence time of between 4 and 13 months depending on precipitation patterns (Cunha \& Calijuri, 2011).

The periphytic community was sampled five times during the year 2010 at two locations in the reservoir from stands of aquatic macrophytes dominated by Polygonum punctatum Ell. Site BR1 (UTM 23K 0266956/7385031) was located at the mouth of the Campo Verde stream, and site BR3 (UTM 23K 0264430/7381817) was located at the point where the Ressaca stream discharges into the transitional zone of the reservoir (Cunha \& Calijuri, 2011) (Fig. 1). Both sampling sites were situated in regions with a mixture of agricultural plantations and residential condominiums.

Rainfall data were obtained from the meteorological station located in the municipality of Ibiúna from the Centre for Integrated Agrometeorological Information's (CIIAGRO) website. The following physical and chemical parameters of the water were measured in situ: $\mathrm{pH}$, conductivity, water temperature (YSI 63-50 FT probe), and dissolved oxygen (YSI 55-12 FT probe). The laboratory analyses included quantification of total Kjeldahl nitrogen, total phosphorous, dissolved inorganic phosphate, total dissolved phosphate, nitrites, and nitrates by the methods described in APHA (2005). The transparency of the water was evaluated using a Secchi disc. Sampling was not possible at site BR3 in September or at site BR1 in November, due to low water levels in the reservoir that prevented access to the sampling sites by boat.
The periphyton attached to the petioles of $P$. punctatum was collected in triplicate at the sampling stations using frames (area $0.0156 \mathrm{~m}^{2}$ ) thrown randomly onto the stands of aquatic macrophytes. In the laboratory, the periphyton was removed from the macrophytes using a brush and jets of distilled water. Aliquots were taken to determine the dry weight, ash-free dry weight, and ash, as described by APHA (2005). Chlorophyll- $a$ and pheophytin were measured using ethanol as a solvent, according to Nush (1980), using modifications described in norm NEM 6520 (Netherlands Norm, 1981). Elemental analysis of the dry macerated periphyton (in terms of the quantities of carbon, nitrogen, hydrogen, and sulphur) was performed using an elemental analyser (Model EA1110, CE Instruments).

The periphyton was classified according to its biomass and inorganic and/or organic content using the index proposed by Lakatos (1989). The Autotrophic Index (APHA, 2005) was also used, enabling inferences to be made concerning the successional phases of the periphytic communities, classifying them as either autotrophic or heterotrophic.

An exploratory analysis and Shapiro-Wilk test (Shapiro \& Wilk, 1965) were applied to verify data normality $(\alpha=0.05)$. In the absence of normality, data were log-transformed. The Pearson test was used to identify linear correlations between the water's physical and chemical variables, and the biological variables. To explore the relationships between the physical and chemical variables of the water and the periphytic biomass, we applied an analysis of Partial Least Squares (PLS). According to Eriksson et al. (2001), PLS analysis is recommended for analysing data with many noisy, collinear and incomplete variables for both $X$ and $Y$. All of the statistical analyses were performed using Statistica v. 8 software (Statsoft Inc. 2007).

\section{RESULTS}

Precipitation in the Itupararanga reservoir region varied between $3.6 \mathrm{~mm}$ (August) and $342.8 \mathrm{~mm}$ (January), with an annual mean of $114.7 \mathrm{~mm}$. 
Water temperature showed little variation between the periods studied $(\mathrm{CV}=18.32 \%)$ (Table 1). Water $\mathrm{pH}$ was basic during February and near neutral during the other months. The concentration of dissolved oxygen varied widely $(\mathrm{CV}=$ $=35.21 \%$ ) and was significantlylower in November than during all other periods. Water conductivity was similar at all sampling dates (Table 1).

Operation of the reservoir (Fig. 2) had a substantial influence on the physical and chemical characteristics of the water. The water level showed a positive correlation with transparency $(r=0.9, \quad p<0.01)$ and with total nitrogen concentration $(r=0.8, \quad p<0.05) \quad$ (Table 2$)$. The inflow into the reservoir was positively correlated with both water temperature $(r=0.8$, $p<0.01)$ and transparency $(r=0.7, p<0.05)$, while reservoir outflow was positively correlated with both water temperature $(r=0.9, p<0.01)$ and $\mathrm{pH}(r=0.8, p<0.01)$. The concentrations of total dissolved phosphorous and dissolved inorganic phosphorous showed no seasonality. However, the total nitrogen concentration was highly variable $(\mathrm{CV}=90.5 \%)$ and fluctuated between values lower than the detection limit and $0.47 \mathrm{mg} \mathrm{L}^{-1}$, with the highest values being measured during February 2010 (Table 1). Nitrites exhibited substantial temporal variability $(\mathrm{CV}=104.3 \%)$ and no obvious seasonal trends. The nitrate concentrations exhibited their lowest values during June 2010 (Table 1).

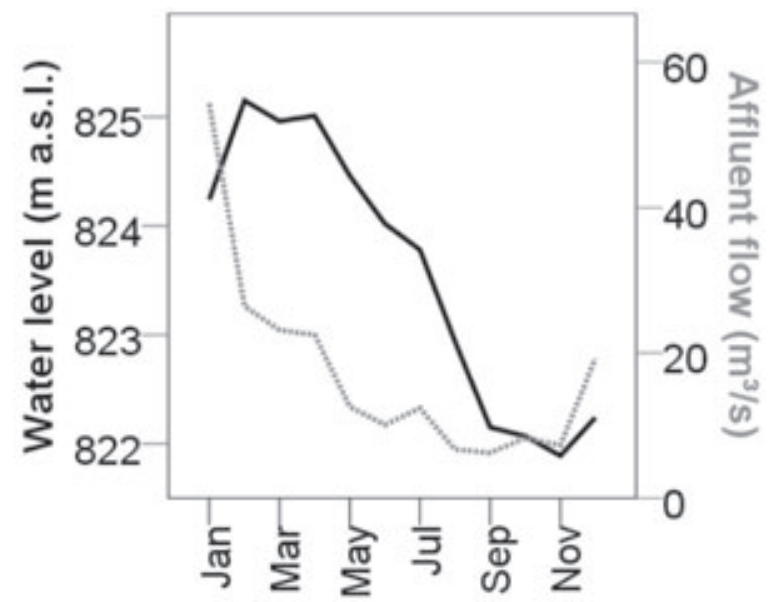

Figure 2. Water level (m.a.s.1.) (black line) and inflow (grey line) in the Itupararanga reservoir during the study period. Cota (m.s.n.m.) (línea negra) y el flujo entrante (línea gris) en el embalse Itupararanga durante el periodo de estudio.

Table 2. Values of the correlations between the physical and chemical variables of the water and the operation of the Itupararanga reservoir. Coeficientes de correlación entre las variables físicas y químicas del agua y del funcionamiento del embalse Itupararanga.

\begin{tabular}{cccc}
\hline \multirow{2}{*}{ Variables } & \multicolumn{3}{c}{ Reservoir operation } \\
\cline { 2 - 4 } & Water level & Inflow & Outflow \\
\hline $\mathrm{TN}$ & $0.82(p \leq 0.05)$ & & \\
$\mathrm{zDS}$ & $0.92(p \leq 0.01)$ & $0.75(p \leq 0.05)$ & \\
$\mathrm{T}$ & & $0.87(p \leq 0.01)$ & $0.91(p \leq 0.01)$ \\
$\mathrm{pH}$ & & & $0.83(p \leq 0.01)$ \\
\hline
\end{tabular}

Table 1. Values of physical and chemical variables of the surface water (minimum, maximum, mean, coefficient of variation $(\mathrm{CV})$ and standard error (SE)) of the Itupararanga reservoir during the study period at sampling stations (SS) BR1 and BR3, $n=8$.

* Below detection limit. Valores de las variables físicas y químicas de las aguas superficiales (mínimo, máximo, media, coeficiente de variación $(C V)$ y el error estándar (SE) del embalse Itupararanga durante el periodo de estudio en las estaciones de muestreo BR1 y BR3, $\mathrm{n}=8$. * Por debajo del límite de detección.

\begin{tabular}{|c|c|c|c|c|c|c|c|c|c|c|c|c|c|c|c|}
\hline SS/month & $\mathrm{T}$ & $\mathrm{pH}$ & $\mathrm{EC}$ & $\mathrm{Zds}$ & DO & $\mathrm{TP}$ & DTP & DIP & $\mathrm{TN}$ & $\mathrm{NO}_{2}^{-}$ & $\mathrm{NO}_{3}^{-}$ & $\% \mathrm{C}$ & $\% \mathrm{~N}$ & $\% \mathrm{H}$ & TN:TP \\
\hline BR1/02 & 28.8 & 8.2 & 50.0 & 1.7 & 7.4 & 26.26 & 19.20 & 3.82 & 0.42 & 0.04 & 0.52 & 32.15 & 2.71 & 4.95 & 15.1 \\
\hline BR3/02 & 29.1 & 9.8 & 52.0 & 1.6 & 7.9 & 29.42 & 15.04 & 2.25 & 0.47 & 0.01 & 0.51 & 23.57 & 1.76 & 4.44 & 15.1 \\
\hline BR1/04 & 24.4 & 7.2 & 63.2 & 2 & 6.3 & 23.60 & 10.16 & 3.49 & 0.11 & 0.06 & 0.43 & 23.49 & 1.75 & 3.85 & 4.6 \\
\hline BR3/04 & 23.4 & 6,8 & 66.0 & 1.5 & 6,5 & 20.45 & 3.08 & 1.26 & 0.16 & 0.03 & 0.42 & 21.75 & 1.72 & 3.88 & 7.6 \\
\hline BR1/06 & 18.0 & 6.9 & 62.7 & 1,7 & 6.1 & 32.66 & 20.71 & 1.38 & 0.14 & 0.22 & 0.31 & 22.51 & 1.98 & 4.07 & 4.0 \\
\hline BR3/06 & 19.1 & 7.3 & 64.3 & 1.1 & 8.5 & 113.61 & 12.46 & 0.96 & 0.23 & 0.16 & 0.34 & 17.88 & 2.17 & 3.52 & 1.9 \\
\hline BR1/09 & 19.6 & 7.3 & 60.2 & 0.5 & 9.1 & 49.12 & 14.27 & 2.59 & $*$ & $*$ & 0.37 & 20,06 & 1.97 & 3.65 & 0 \\
\hline BR3/11 & 22.3 & 7.5 & 37.0 & 0.2 & 1.5 & 89.27 & 17.10 & 2.13 & $*$ & 0.06 & 0.84 & 6.53 & 0.65 & 2,39 & 0 \\
\hline Mean & 23.1 & 7.6 & 56.9 & 1.4 & 6.7 & 48.04 & 14.00 & 2,23 & 0.19 & 0.07 & 0.46 & 21.01 & 1.86 & 3.84 & 6.03 \\
\hline CV (\%) & 18.3 & 12.8 & 17.4 & 54.4 & 35.2 & 72.16 & 39.96 & 46.41 & 90.58 & 104.33 & 35.93 & 51.72 & 0.32 & 0.54 & 37.56 \\
\hline
\end{tabular}


The TN:TP atomic ratio varied between 0 and 14 at the two sites (Table 1); according to Guildford \& Hecky (2000), values below 20 are characteristic of nitrogen limitation.

The ash-free dry weight (AFDW) of periphyton was similar at both sampling sites at most sampling times, with the exception of site BR3 in November, when higher values were measured (Fig. 3). The lowest values were obtained in June when the water temperature was lower (Figs. 1 and 4). AFDW was negatively correlated with conductivity $(r=-0.8, p \leq 0.01)$, transparency $(r=-0.6, p \leq 0.05)$, dissolved oxygen $(r=-0.8, p \leq 0.01)$, and total nitrogen $(r=-0.9$, $p \leq 0.01)$ and was positively associated with nitrate concentration $(r=0.9, p \leq 0.01)$.

The chlorophyll- $a$ content of the periphyton (Fig. 3) remained fairly constant during the months of February, April, and June, but increased at site BR1 in September and at site
BR3 in November. Chlorophyll- $a$ was negatively correlated with water transparency $(r=-0.9$, $p \leq 0.01)$, total nitrogen $(r=-0.7, p \leq 0.01)$, and nitrites $(r=-0.6, p \leq 0.05)$.

The concentrations of carbon, nitrogen, and hydrogen in the periphytic community were generally higher during the rainy season (Fig. 4). The concentrations of sulphur were below the detection limit for the method employed.

The carbon content of the periphytic community was negatively correlated with water transparency $(r=-0.6, p \leq 0.05)$, dissolved oxygen $(r=-0.7, p \leq 0.01)$, and total nitrogen $(r=-0.8, p \leq 0.01)$, but was positively correlated with the nitrate concentration in the water $(r=0.9, p \leq 0.01)$.

The nitrogen content of the periphyton was negatively correlated with water conductivity $(r=-0.8, \quad p \leq 0.01)$, transparency $(r=-0.7$, $p \leq 0.05)$, dissolved oxygen $(r=-0.7, p \leq 0.01)$,
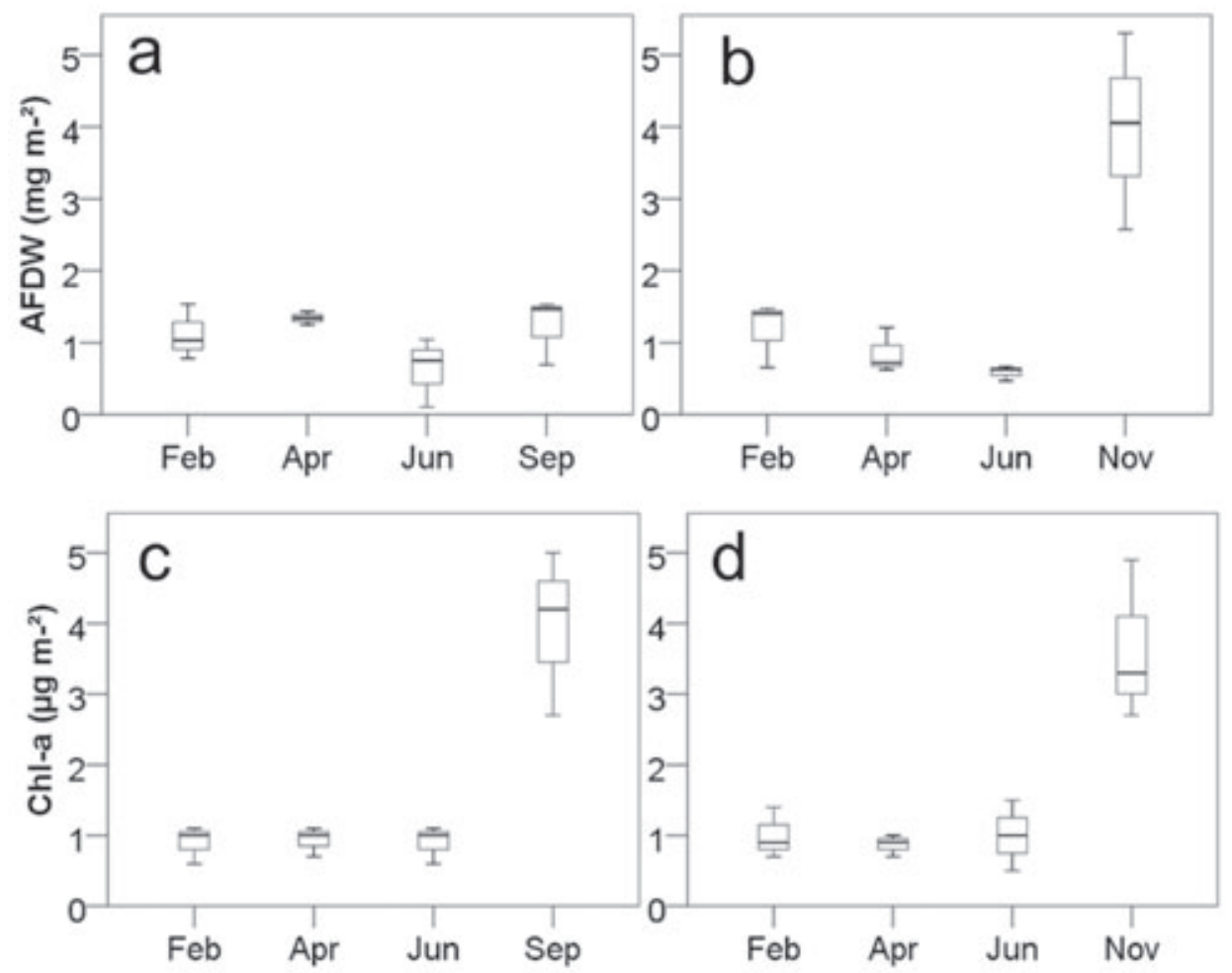

Figure 3. Periphytic biomass expressed as ash free dry weight (AFDW) at the BR1 (a) and BR3 (b) sampling stations and chlorophyll- $a$ at the BR1 (c) and BR3 (d) sampling stations. Biomasa del perifiton expresada en peso seco libre de cenizas (AFDW) en las estaciones de muestreo BRI (a) y BR3 (b) y clorofila-a en las estaciones de muestreo BRI (c) y BR3 (d). 
and total nitrogen $(r=-0.9, p \leq 0.01)$, but was positively correlated with the water nitrate concentration $(r=0.9, p \leq 0.01)$.

The total carbon concentrations of the periphytic community in the Itupararanga reservoir were lower than those found in previous studies undertaken both in Brazil and in temperate regions (Table 3). In the present study, the concentration of carbon varied between 0.3 and $1.2 \mathrm{~m} \mathrm{C} \mathrm{m}^{2}$, with the highest concentration measured at site BR3 in November, and the lowest concentration at site BR3 in April.

The PLS analysis with five independent variables (nitrates, conductivity, dissolved oxygen, water transparency and dissolved inorganic phosphorous) produced two components, where $94.3 \%$ of the sum of squares of the dependent variables had been explained by all the extracted components. The predicted variation was $62 \%$, suggesting a reasonably good model (Table 4). The variables that had the greatest influence on the model were nitrates (VIP $=0516$ ), conductivity (VIP $=0492)$, dissolved oxygen (VIP = 0462), water transparency (VIP $=0416)$ and dissolved inorganic phosphorous ( VIP $=0320)$.

According to the autotrophic index (APHA, 2005) the periphytic communities could be classified as heterotrophic at both sites and during all periods (Table 5). The index proposed by Lakatos (1989) indicated that the periphytic community at site BR1 generally had a higher organic con- tent, while the periphyton from site BR3 exhibited similar proportions of organic and inorganic materials (Table 5). Both sites were characterised by low levels of biomass throughout the study period according to the Lakatos index (1989).

\section{DISCUSSION}

The monthly precipitation and temperature data clearly distinguished the driest period (June) from the rainy period (February, April, September, and November). The volume and inflow of the reservoir declined continuously after July, which sometimes made it impossible to sample during periods of low water. The inflow of the reservoir, which correlates with precipitation rates, was positively correlated with temperature and with water transparency, indicating that when water entered the reservoir, there was a dilution of total solids that favoured transparency. In a study of the Itaipu reservoir, Ribeiro Filho $e t$ al., (2011) observed that chemical, physical and limnological variables were strongly dependent on the hydrological regime, which supports our results. In contrast, for Brazilian reservoirs, no marked seasonality was observed for the total or dissolved nutrient concentrations, except for nitrates. This could have been due to the location of the sampling sites in branches of the central section of the reservoir with intermediate

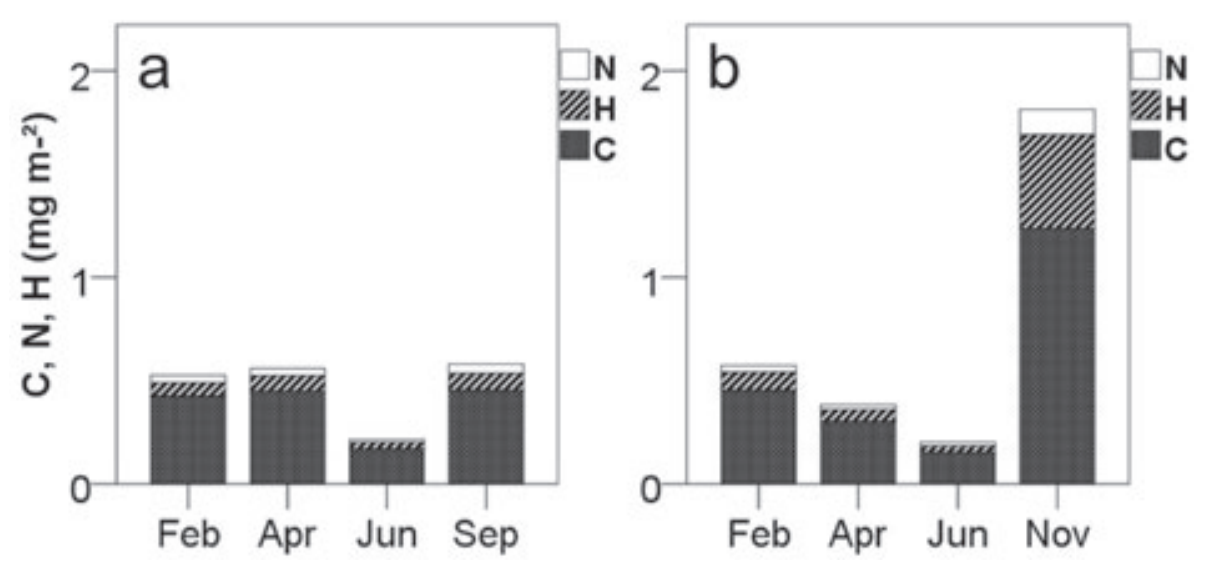

Figure 4. Concentrations of carbon $(\mathrm{C})$, nitrogen $(\mathrm{N})$ and hydrogen $(\mathrm{H})$ in the dry weight of periphyton (DW) at the BR1(a) and BR3(b) sampling stations. Concentraciones de carbono $(C)$, nitrógeno $(N)$ y de hidrógeno $(H)$ del peso seco del perifiton $(D W)$ en las estaciones de muestreo BRl (a) y BR3 (b). 
Table 3. Concentrations of carbon in the periphytic biomass at different locations and on different substrata. Concentraciones de carbono en la biomasa perifítica en localidades y sustratos diferentes.

\begin{tabular}{llll}
\hline Study area & Substratum & Carbon & Reference \\
\hline Jurumirim Reservoir (SP, Brazil) & Natural substratum (macrophyte) & $14.5-52.1 \%$ DW & Moschini-Carlos et al. (1998) \\
Boreal lakes (ON, Canada) & Artificial substratum & $6-15 \mathrm{mgC} \mathrm{m}^{2}$ & Frost \& Elser (2002) \\
Boreal lakes (ON, Canada) & Natural substratum (rock) & $14-60 \mathrm{mgC} \mathrm{m}^{2}$ & Frost \& Elser (2002) \\
Érken lake (Sweden) & Natural substratum (rock) & $1,5 \mathrm{mgC} \mathrm{\textrm {m } ^ { 2 }}$ & Kahlert et al. (2002) \\
Cabiúna lagoon (RJ, Brazil) & Artificial substratum & $2.2-2.6 \mathrm{mgC} \mathrm{m}^{2}$ & Guariento et al. (2011) \\
\hline
\end{tabular}

characteristics between fluvial and lacustrine zones (Thornton et al., 1990), hence masking any possible seasonal behaviour of the nutrients.

Periphyton biomass (AFDW) and chlorophyll- $a$ were at their lowest in June (dry period), which was associated with lower water temperatures and a lower concentration of nitrates. This result demonstrates the importance of nitrates to the development of benthic producers, as detected by Axler \& Reuter (1996), who demonstrated that periphyton was responsible for consuming $56 \%$ of the nitrates in an experiment in a mesocosm and that temperature influenced algal growth (Roberts et al., 2003) but contrasted with results found in Brazilian reservoirs (Borduqui et al., 2008; Moschini-Carlos et al., 2000), where greater biomass was found during dry periods.

The carbon, nitrogen, and hydrogen concentrations of the periphytic community also exhibited seasonal variations, with the highest values found during the rainy period. Positive correlations were found between the water volume in the reservoir and the concentration of total nitrogen, which had a positive relationship with the periphytic biomass and composition. This factor may be associated with surface runoff during the rainy season, where nutrients are carried into water bodies, thus promoting the development of the periphytic community. The concentrations of carbon and nitrogen in the periphytic community also showed strong correlations with nitrate concentrations. In a study of the Jurumirim reservoir (São Paulo State, Brazil), Moschini-Carlos et al. (1998) also found positive relationships between the elemental composition of the periphyton and the hydrological regime, which supports our hypothesis.

Nitrogen was the limiting nutrient throughout the study period at both sites, according to the TN:TP ratios (Guildford \& Hecky, 2000) for phytoplankton. In previous work undertaken at the same reservoir, Cunha \& Calijuri (2011) also reported nitrogen limitations for the phytoplankton community in the fluvial and lacustrine zones (TN:TP atomic ratio $=11-\sim 35$ ). In the Ninféias reservoir (São Paulo, Brazil), which has mesotrophic characteristics, Ferragut et al. (2010) found that the periphytic community

Table 4. Model fitting results of the PLS analysis performed with the independent (nitrate, conductivity, dissolved oxygen, water transparency and dissolved inorganic phosphorous) and dependent (AFDW) variables. $k=$ component number, $R^{2} X=$ fraction of sum of squares of all the $X$ s explained by the component, $R^{2} X$ (cumul.) = accumulated $R^{2} X, R^{2} Y=$ fraction of sum of squares of all the $Y$ s explained by the component, $R^{2} Y$ (cumul.) = accumulated $R^{2} Y, Q^{2}=$ fraction of the total variation of the Xs and Ys that can be predicted by the component, $Q^{2}$ (cumul.) = accumulated $Q^{2}$. Resultados del ajuste del modelo PLS con las variables independientes (nitratos, conductividad, oxígeno disuelto, transparencia del agua y el fósforo inorgánico disuelto) y las independientes (AFDW). $\mathrm{k}=$ número de componentes, $\mathrm{R}^{2} \mathrm{X}=$ fracción de la suma de los cuadrados de todas las variables independientes explicados por el componente, $\mathrm{R}^{2} \mathrm{X}$ (cumul.) $=\mathrm{R}^{2} \mathrm{X}$ acumulado, $\mathrm{R}^{2} Y=$ fracción de la suma de los cuadrados de todas las variables dependientes explicados por el componente. $\mathrm{R}^{2} \mathrm{Y}$ (cumul.) $=\mathrm{R}^{2} \mathrm{Y}$ acumulado, $\mathrm{Q}^{2}=$ fracción de la variación total de las variables dependientes e independientes que se puede predecir por los componentes, $\mathrm{Q}^{2}$ (cumul.) $=\mathrm{Q}^{2}$ acumulado.

\begin{tabular}{cccccccc}
\hline$k$ & $R^{2} X$ & $R^{2} X$ (Cumul.) & Eigenvalues & $R^{2} Y$ & $R^{2} Y$ (Cumul.) & $Q^{2}$ & $Q^{2}$ (Cumul.) \\
\hline 1 & 0.660995 & 0.660995 & 3.281698 & 0.916392 & 0.916392 & 0.70133 & 0.70133 \\
2 & 0.207576 & 0.868571 & 0.79547 & 0.026816 & 0.943207 & -0.241733 & 0.629132 \\
\hline
\end{tabular}


was limited by phosphorous, except during spring (TN:TP atomic ratio $=3.2-\sim 87$ ). The concentrations of phosphorous were available throughout the period of the study and were similar to those measured in other subtropical Brazilian reservoirs (Cunha \& Calijuri, 2011).

The PLS analysis demonstrated a strong influence of nitrates but also of the conductivity on the development of periphytic biomass. Various studies have attributed concentrations of ions in the water to anthropogenic activities such as land use and occupation and the discharge of domestic effluents. In a study of rivers in the Middle Rio Doce basin, Petrucio et al. (2005) suggested that secondary bacterial production was highly sensitive to changes in the concentrations of nitrogen and phosphorous as well as to the conductivity of the water.

Recent studies have demonstrated the importance of riparian vegetation for the control of nitrate input in aquatic ecosystems because nitrates are an important nutrient for the development of primary producers. Sobota et al. (2012) demonstrated that streams near agricultural and urban centres have higher rates of nitrates and attributed this to the lack of riparian vegetation, suggesting that the maintenance and restoration of riparian vegetation may contribute to the reestablishment of the natural rate of nitrate uptake. In another study, Weller et al. (2011) concluded through modeling that the restoration of riparian vegetation could contribute substantially to the reduction of nitrates in water. In another study in the same reservoir, Taniwaki et al. (2013) observed that land use and occupation around the reservoir contribute to nutrient concentrations and the genotoxicity of water. All of these studies support our results, given that the Itupararanga reservoir has a reduced cover of riparian vegetation in its surroundings, favouring the input of nitrates and thus the development of a periphyton community, particularly during the rainy season, when the highest rates of runoff occur.

The periphyton showed an average concentration of $21 \%$ carbon in its biomass. In a study that analysed over 5000 pieces of data, it was found that algae in the periphytic community contributed approximately $8.4 \%$ of the total carbon in the periphytic biomass (Frost et al., 2005). According to the authors, the remainder of the carbon in the periphyton was due to the production of mucilage and other organic materials by bacteria and algae. Moschini-Carlos et al. (1998) and Guariento et al. (2011) measured average concentrations of carbon in the periphytic biomass that were higher than those found in the present study. One possible explanation for this fact might be the different types of substrate colonisation of periphyton, as was observed by Zebek (2009).

Table 5. Periphyton type according to the Autotrophic Index - AI (APHA, 2005) and Lakatos (1989). Tipo de perifiton de acuerdo con el Índice de autotrofia - AI (APHA, 2005) y Lakatos (1989).

\begin{tabular}{cccccc}
\hline Sample date & Type of biomass & Ash $\%$ & Type & AI & Type \\
\hline & & \multicolumn{2}{c}{ BR1 } & & \\
\hline Feb & Low & 15.5 & organic & 1114 & Heterotrophic \\
Apr & Low & 29.9 & organic & 1594 & Heterotrophic \\
Jun & Low & 16.2 & organic & 657 & Heterotrophic \\
Sep & Low & 45.7 & org-inorg & 312 & Heterotrophic \\
\hline & & & & & HR3 \\
Feb & Low & 38.9 & org-inorg & 1349 & Heterotrophic \\
Apr & Low & 39.1 & org-inorg & 907 & Heterotrophic \\
Jun & Low & 31.5 & org-inorg & 633 & Heterotrophic \\
Nov & Low & 79.0 & inorg & 1086 & Heterotrophic \\
\hline
\end{tabular}




\section{CONCLUSIONS}

In this study, we found that the biomass and elemental composition of the periphytic community is dependent on the season and is controlled principally by the concentration of nitrate in the water. This result demonstrates the importance of maintaining riparian vegetation and managing effluents to control the input of nitrates into the reservoir and thus control primary production and the production of organic matter in the Itupararanga reservoir.

\section{ACKNOWLEDGMENTS}

The authors are grateful to CAPES for the scholarship provided to the first author, to FAPESP for research funding (Proc. 08/55636-9), to Adriana Cristina Poli Miwa for administrative and laboratory support and to two anonymous reviewers for important considerations in our study.

\section{REFERENCES}

APHA. 2005. Standard Methods for the Examination of Water and Wastewater, $21^{\text {st }}$ ed. American Public Health Association, Washington DC.

AXLER, R. \& J. E. REUTER. 1996. Nitrate uptake by phytoplankton and periphyton: Whole-lake enrichments and mesocosm $15 \mathrm{~N}$ experiments in an oligotrophic lake. Limnology and Oceanography, 41 (4): 659-671.

BORDUQUI, M., C. FERRAGUT \& C. E. M. BICUDO. 2008. Chemical composition and taxonomic structure vertical and seasonal variation of periphyton community in a shallow eutrophic reservoir (Garças Reservoir, São Paulo). Acta Limnologica Brasilensia, 20: 381-392.

CONCEIÇÃO, F. T., D. D. SARDINHA, G. R. B. NAVARRO, M. L. P. ANTUNES \& V. A. ANGELUCCI. 2011. Rainwater chemical composition and annual atmospheric deposition at Alto Sorocaba Basin (SP). Quimica Nova, 34: 610-658.

CUNHA, D. G. F. \& M. D. CALIJURI. 2011. Limiting factors for phytoplankton growth in subtropical reservoirs: the effect of light and nutrient availability in different longitudinal compartments. Lake and Reservoir Management, 27: 162-172.
ELSDON, T. S. \& K. E. LIMBURG. 2008. Nutrients and their duration of enrichment influence periphyton cover and biomass in rural and urban streams. Marine and Freshwater Research, 59: 467-476.

ERIKSSON, L., E. JOHANSSON, N. KETTANNEHWOULD, S. WOULD. 2001. Multi- and Megavariate Data Analysis. Principles and Applications. Umetrics Academy. Umea.

FERMINO, F. S., C. E. M. BICUDO \& D. C. BICUDO. 2011. Seasonal influence of nitrogen and phosphorus enrichment on the floristic composition of the algal periphytic community in a shallow tropical, mesotrophic reservoir (São Paulo, Brazil). Oecologia Australis, 15: 476-493.

FERRAGUT, C., A. F. RODELLO \& C. E. M. BICUDO. 2010. Seasonal variability of periphyton nutrient status and biomass on artificial and natural substrates in a tropical mesotrophic reservoir. Acta Limnologica Brasiliensia, 22: 397-409.

FROST, P. C. \& J. J. ELSER. 2002. Effects of light and nutrients on the net accumulation and elemental composition of epilithon in boreal lakes. Freshwater Biology, 47: 173-183.

FROST, P. C., H. HILLEBRAND \& M. KAHLERT. 2005. Low algal carbon content and its effect on the C:P stoichiometry of periphyton. Freshwater Biology, 50: 1800-1807.

GUARIENTO, R. D., A. CALIMAN, F. A. ESTEVES, R. L. BOZELLI, A. ENRICH-PRAST \& V. F. FARJALLA. 2009. Substrate influence and temporal changes on periphytic biomass accrual and metabolism in a tropical humic lagoon. Limnologica, 39: 209-218.

GUARIENTO, R. D., L. S. CARNEIRO, A. CALIMAN, R. L. BOZELLI, \& F. A. ESTEVES. 2011. How light and nutrients affect the relationship between autotrophic and heterotrophic biomass in a tropical black water periphyton community. Aquatic Ecology, 45 (4): 561-569.

GUASCH, H. \& S. SABATER. 1998. Light history influences the sensitivity to atrazine in periphytic algae. Journal of Phycology, 34: 233-241.

GUILDFORD, S. J. \& R. E. HECKY. 2000. Total nitrogen, total phosphorus, and nutrient limitation in lakes and oceans: Is there a common relationship? Limnology and Oceanography, 45: 1213-1223.

KAHLERT, M., A. T. HASSELROT, H. HILLEBRAND \& K. PETTERSSON. 2002. Spatial and temporal variation in the biomass and nutrient status of epilithic algae in Lake Erken, Sweden. Freshwater Biology, 47: 1191-1215. 
LAKATOS, G. 1989. Composition of reed periphyton (biotecton) in the Hungarian part of Lake Fertö. Biologisches Forschungsinstitut für Burgenland, 71: 125-134.

MOSCHINI-CARLOS, V., M. L. M. POMPÊO \& HENRY, R. 1998. Temporal variation in C, N and $\mathrm{P}$ of the periphyton on tropical aquatic macrophyte Echinochloa polystachya (H.B.K.) Hitch. in Jurumirim reservoir (São Paulo, Brasil). Japanese Journal of Limnology, 59: 281-294.

MOSCHINI-CARLOS, V., R. HENRY \& M. L. M. POMPÊO. 2000. Seasonal variation of biomass and productivity of the periphytic community on artificial substrata in the Jurumirim Reservoir (Sao Paulo, Brazil). Hydrobiologia, 434: 35-40.

MOSCHINI-CARLOS, V., M. L. M. POMPÊO \& R. HENRY. 2001. Periphyton on natural substratum in Jurumirim reservoir (São Paulo, Brazil): Community biomass and primary productivity. International Journal of Ecology and Environmental Sciences, 27: 171-177.

NEDERLANDSE NORM 6520. 1981. Water: spectrofotometrische bepaling van het gehalte aan chlorofyl-a. NEN Rep. Nederlands Normalisatieinstituut, Postbus 5059, 2600 GB Delft, The Netherlands.

NUSH, E.A. 1980. Comparison of different methods for clorophyll and phaeopigment determination. Archiv für Hydrobiologie-Beiheft Ergebnisse der Limnologie, 14: 14-36.

PEDRAZZI, F. J. M., F. T. CONCEIÇÃO, D. S. SARDINHA, V. MOSCHINI-CARLOS \& $\mathrm{M}$. POMPÊO. 2013. Spatial and temporal quality of water in the Itupararanga Reservoir, Alto Sorocaba Basin (SP), Brazil. Journal of Water Resource and Protection, 5: 64-71.

PETRUCIO, M., F. BARBOSA \& S. THOMAZ. 2005. Bacteria and phytoplankton production rates in eight river stretches of the Middle Rio Doce hydrographic basin (southeast Brazil). Brazilian Archives of Biology and Technology, 48: 487-496.

RIBEIRO FILHO, R. A., M. PETRERE-JR., S. F. BENASSI \& J. M. A. PEREIRA. 2011. Itaipu Reservoir limnology: Eutrophication degree and the horizontal distribution of its limnological variables. Brazilian Journal of Biology, 71: 889-902.

ROBERTS, E., J. KROKER, S. KORNER \& A. NICKLISCH. 2003. The role of periphyton during the re-colonization of a shallow lake with submerged macrophytes. Hydrobiologia, 506: $525-530$.
SANCHES, L. F., R. D. GUARIENTO, A. CALIMAN, R. L. BOZELLI \& F. A. ESTEVES. 2011. Effects of nutrients and light on periphytic biomass and nutrient stoichiometry in a tropical black-water aquatic ecosystem. Hydrobiologia, 669: 35-44.

SARDINHA, D. S., D. M. BONOTTO \& F. T. CONCEICAO. 2010. Weathering rates at Alto Sorocaba basin, Brazil, using U-isotopes and major cations. Environmental Earth Sciences, 61: 1025-1036.

SHAPIRO, S. S. \& M. B. WILK. 1965. An analysis of variance test for normality (complete samples). Biometrika, 52: 591-611.

SMITH, W. S. \& M. PETRERE-JR. 2008. Spatial and temporal patterns and their influence on fish community at Itupararanga Reservoir, Brazil. Revista de Biologia Tropical, 56: 2005-2020.

SOBOTA, D. J., S. L. JOHNSON, S. V. GREGORY, L. R. ASHKENAS. 2012. A Stable Isotope Tracer Study of the Influences of Adjacent Land Use and Riparian Condition on Fates of Nitrate in Streams. Ecosystems, 15: 1-17.

STATSOFT, INC. 2007. STATISTICA (data analysis software system), version 8.0. www.statsoft.com.

TANIWAKI, R. H., A. H. ROSA, R. LIMA, C. R. MARUYAMA, L. F. SECCHIN, M. C. CALIJURI \& V. MOSCHINI-CARLOS. 2013. The influence of land use and occupation on the quality and genotoxicity of water in the Itupararanga Reservoir, São Paulo, Brazil. Interciencia, 38 (3): 164-170.

THORNTON, K. W., B. L. KIMMEL \& F. E. PAYNE. 1990. Reservoir Limnology: Ecological Perspectives. Wiley-Interscience, New York (NY).

TRANVIK, L. J., J. A. DOWNING, J. B. COTNER, S. A. LOISELLE, R. G. STRIEGL, T. J. BALLATORE, P. DILLON, K. FINLAY, K. FORTINO, L. B. KNOLL, P. L. KORTELAINEN, T. KUTSER, S. LARSEN, I. LAURION, D. M. LEECH, S. L. MCCALLISTER, D. M. MCKNIGHT, J. M. MELACK, E. OVERHOLT, J. A. PORTER, Y. PRAIRIE, W. H. RENWICK, F. ROLAND, B. S. SHERMAN, D. W. SCHINDLER, S. SOBEK, A. TREMBLAY, M. J. VANNI, A. M. VERSCHOOR, E. VON WACHENFELDT \& G. A. WEYHENMEYER. 2009. Lakes and reservoirs as regulators of carbon cycling and climate. Limnology and Oceanography, 54: 2298-2314.

TUNDISI, J. G. \& T. MATSUMURA-TUNDISI. 2003. Integration of research and management in optimizing multiple uses of reservoirs: The 
experience in South America and Brazilian case studies. Hydrobiologia, 500: 231-242.

WELLER, D. E., M. E. BAKER \& T. E. JORDAN. 2011. Effects of riparian buffers on nitrate concentrations in watershed discharges: new models and management implications. Ecological Applications, 21 (5): 1679-1695.

WETZEL, R. G. 1990. Land-water interfaces: meta- bolic and limnological regulators. Verhandlungen des Internationalen Verein Limnologie, 24: 6-24. WETZEL, R. G. 1963. Primary productivity of periphyton. Nature, 197: 1026-1027.

ZEBEK, E. 2009. Comparison of plant periphyton on the different substrates in the vicinity of the water power station on the Pasleka River. Oceanological and Hydrobiological Studies, 38: 133-138. 
